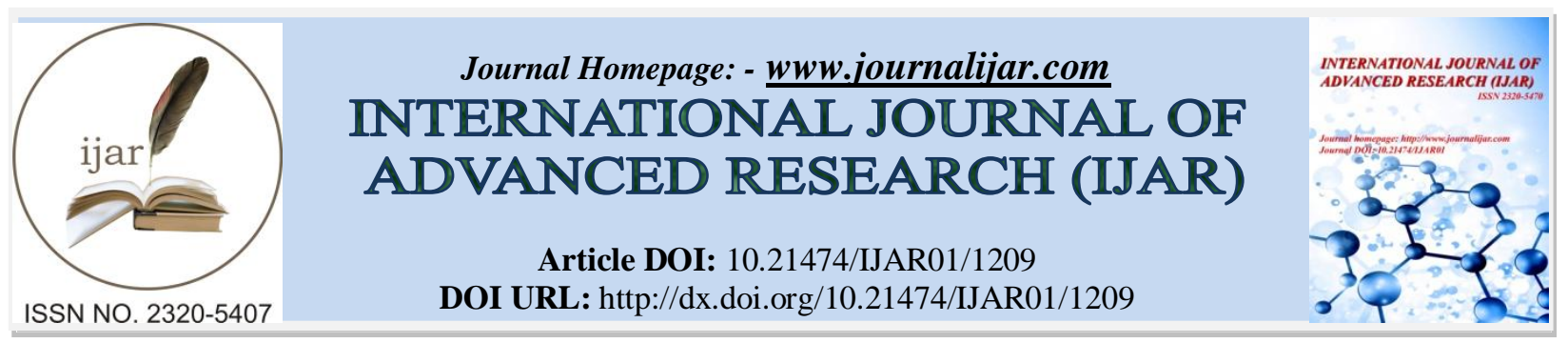

RESEARCH ARTICLE

\title{
HIGHER EDUCATION QUALITY CONTROL ANALYSIS OF PRIVATE HIGHER EDUCATION INSTITUTIONS CONDUCTED BY PRIVATE HIGHER EDUCATION COORDINATING BOARD OF REGION III JAKARTA.
}

Eko Sugiyanto.

National of University Graduate Lecturer, Jakarta.

\section{Manuscript Info}

Manuscript History

Received: 19 June 2016

Final Accepted: 18 July 2016

Published: August 2016

Key words:-

Control, higher education, and quality.

\section{Abstract}

This study was stimulated by general lack of non-optimal quality of private higher education found by Private Higher Education Coordinating Boardof Region III Jakarta indirectly affecting the tendency of declined performance of Three Pillars of Higher Education and the assessment of private higher education accreditation. By using qualitative approach to overcome this problem, the higher education quality control process conducted by Private Higher Education Coordinating Board of Region III Jakarta needs to be analyzed through the stages whose concept was developed by George and Jones (2006), including: establishing the performance standards, measuring actual performance, adjusting actual performance with the standards, evaluating the results and applying improvement if standards are not achieved. The result shows that the private higher education quality control conducted by Private Higher Education Coordinating Boardof Region III Jakarta has been running effectively that proceeds through four stages.

Copy Right, IJAR, 2016,. All rights reserved.

\section{Introduction:-}

The competitiveness of a nation is closely related to the participation of higher education institutions. Therefore, a significant role must be given to higher education institutions through the implementation of high-quality education that provides ample opportunities for the whole nation, as Article 16 of Act No. 20/2003 on National Education System that gives real and extensive role to the government, the local government along with society (a nongovernmental group of Indonesian citizens who pays attention and role in the field of education) to support education. The role of government, local government along with this community will stimulate the growth of the Gross Enrollment Ratio (GER). Data show that initially in 2003 the number of young people aged 19-24 years who are studying at universities in Indonesia was only 14\%, in 2007 rose to $17.26 \%$. However, compared to countries such as China (20.3\%), Malaysia (32.5\%), Thailand (42.7\%), and Korea (91\%), it appears that Indonesia is still struggling to raise the GER.

The opportunity to raise GER is widely open, although, nationally, the data of higher education collected by Indonesian Directorate General of Higher Education (DIKTI) only shows one percent increase each year, in which, in academic year of 2013/2014, it increased to 3,016 of higher education institutions, covering 84 state higher education institutions and 2,933 private higher education institutions. Compared to other ASEAN countries, that 
position is still relatively low. Therefore, the access to higher education by increasing the number of students should be carried out continuously and evenly, so as to encourage economic growth and competitiveness of the nation (critical mass).

Increasing the quantity of students should be accompanied by the improvement of quality and high relevance of higher education, because without these two aspects, the graduates would only be "intellectually unemployed" as shown inthe Indonesian Central Bureau of Statistics (BPS: 2014), that in Indonesia there is a high rate of open unemployment derived from higher education, which is about 6-7\% from vocational education and under graduate programs. Strengthened by national labor force survey by the National Development Planning Agency (Bappenas: 2013), it is recorded that from 21.2 million people in Indonesia included in the labor force, 4.1 million people or $22.2 \%$ are unemployed. This condition is more worrisome because the unemployment rate is ranging over two million people and dominated by undergraduates. They are often referred to "intellectually unemployed" or "academic unemployment" (Kompas.com, February 10, 2010). In addition, there is a tendency for lack of vacancies while the penetration of foreign labor is getting higher; thus, the competition in the country does not only exist among national college graduates, but also with graduates from abroad.

Improving the quality and relevance of higher education is not an easy job because it is associated with many factors such as the quality of teachers, educational facilities and infrastructure, financial management, and academic atmosphere created at their respective colleges. Therefore, to ensure the trust of all stakeholders on the management accountability and/or the performance quality of higher education, the government, in accordance with Article 66 of Act No. 20/2003 shall conduct the supervision, control and guidance with the principles of transparency and accountability. To carry out the supervision, control and guidance in private higher education institutions, Indonesian Directorate General of Higher Education is assisted by Private Higher Education Coordinating Board.

As the mediator and implementor of quality policy of Indonesian Directorate General of Higher Education (DIKTI), Private Higher Education Coordinating Board of Region III Jakartais one of the biggest institutions among other Private Higher Education Coordinating Boards, since it consists of 324 private higher education institutions (11\%) of 2,933 private higher education institutions with 1,506 study programs in Indonesia. In fact, there are still a number of private higher education institutions considerably constrained in the implementation of the quality of higher education. Referring to the data obtained from Directorate General of Learning and Students (ditbelmawa) of DIKTI (2013), in the Private Higher Education Coordinating Board of Region III milieu, it is established that: 1) In 2009, there were only six private higher education institutions receiving predicate of good quality implementation; 2) In 2010, there were 11 private higher education institutions receiving predicate of good quality implementation; 3) In 2011, there were five private higher education institutions receiving predicate of good quality implementation; and 4) In 2012, there was none of the private higher education institutionsreceiving predicate of good quality implementation. Meanwhile, the private higher education institutions obtained accreditation as follows; 104 institutions obtained 'A' grade, 424 institutions obtained 'B' grade, 266 institutions obtained 'C' grade, 207 institutions obtained expired grade, and 547 institutions have never been accredited.

The low number of private higher education institutions receiving predicate of good quality implementation is indirectly describing that the implementation of higher education quality control on the private higher education institutions conducted by Private Higher Education Coordinating Board of Region III has not effective yet. If this condition persists without being strategically controlled, it will seriously impact the declining quality of the implementation of Three Pillars of Higher Education (Education, Research and Community Service) as well as the assessment of the institution accreditation. For this reason, this study focuses to find out the quality control of higher education in the private higher education institutions conducted byPrivate Higher Education Coordinating Board of Region III Jakarta.

\section{Research Method:-}

This research applies a qualitative approach. As the procedure, this approach generated descriptive data in the form of written or spoken words of people and behaviors that could be observed so as to enable the observer to comprehend the society and regard them as it was them who reveal their own point of view. In terms of resources, data collection was done using primary sources and secondary sources that would later become the analysis benchmark and observer'sinterpretation. Meanwhile, in terms of technique, data collection was done by using observation, interview, and documentation techniques. 
The data validation was proceeded by using triangulation technique; a technique to examine the validity of data utilizing something other than the data for the purpose of validating or as a comparison against the data. Triangulation techniques in this study include three main elements; data triangulation, researcher triangulation, and theory triangulation.

\section{Conceptual Framework:- \\ Quality:-}

Quality in one's view is sometimes at odds with the views of others, so that conclusion could be varied. For example,Gaspersz (2009: 1) views quality as everything that is able to meet the desires or needs of customers. Otherwise, Deming, as quoted by Sallis (2010: 97), considers that the case of quality is in accordance with the case of management. If managers are seriously concerned about the quality, then they must understand the general and specific causes of quality failure. The common causes are the causes resulting from system failure in which this system problem is an internal matter of institutional process that can only be overcome if the system, process and procedures of the institution are changed.Meanwhile, the specific causes generate non-random variation in the system called external causes. Related to this matter, Joseph Juran states that most quality problems can be returned to the issue of management decision with the $85 / 15$ rule. This meansthat $85 \%$ of the quality problem in an organization is the result of the poor design process; that is why the correct application of the system will lead to good quality result. Eighty five percent of the problem is the responsibility of management, because they have $85 \%$ of the supervision or control of the organizational system (Sallis, 2010: 109).

\section{Control:-}

Plunkett and Attner (1997: 496) consider that the supervision or control is thefunction of management, in which managers define and communicate the performance standards for staff, processes, and equipment. If the supervisor is limited to providing advice,then the following-up activity is carried out by the control since the control has the authority to intervene, which is not owned by the supervisor (Brantas, 2009: 188). Meanwhile, Robbins and DeCenzo (1995: 344) consider that control is a monitoring process of activities to ensure that the standards can be implemented as planned and to take corrective action against significant irrelevancy. Similarly, Puspopranoto (1995: 344) states that:

Control is the process of monitoring activities to ensure that the standards can be implemented as planned and to take corrective action against significant irrelevancy. All managers should be engaged in controlling function even if their working units have run their tasks as planned. An effective control system ensures that the activities have been conducted in ways that can deliver the organization to achieve its objectives.

Griffin (2004: 162) views control as the activity-setting of the organization in order that the performance target elements remain consistent within the acceptable limitation. This means that without the setting, Private Higher Education Coordinating Board of Region III Jakarta does not have a clue about how well their performance is in achieving the specified goals. Related to this matter, George and Jones (2006: 493) explain that:

Controlling is a process where managers monitor and regulate how an organization and its members are efficiently and effectively performing the activities necessary to achieve organizational goals. In this process, managers also monitor and evaluate whether the organization's strategy and structure are working as intended, how they could be improved, and how they might be changed if they are not working. It, however, does not only mean reacting to the events after they have occurred, but also means keeping an organization on track, anticipating events that might occur, and then changing the organization to respond to whatever opportunities and threats have been identified. Control is concerned with keeping employees motivated and focused in the important problems confronting the organization, and working together to make the changes that will help an organization perform more highly over time.

Quality control of higher education in the private higher education institutions conducted by Private Higher Education Coordinating Board of Region III Jakartais a monitoring activity in controlling the quality effectively to achieve the goals that have been set. However, George and Jones (2006: 497) emphasize that: "the control process, whether at the input, conversion, or output stage, can be broken down into four steps: establishing standards of performance, and then measuring, comparing, and evaluating actual performance". The controlling process, whether on the input, conversion, and output stages, can be divided into four steps; establishing performance standards, 
measuring, comparing, and evaluating the real performance.This concept can be analyzed through this four-step organizational control as shown in Figure 1 below.

Figure 1:- Four Steps in Organizational Control.

\begin{tabular}{|c|c|}
\hline Step 1 & $\begin{array}{l}\text { Establishing the standards of performance, goals, or targets } \\
\text { against which performance is to be evaluated. }\end{array}$ \\
\hline Step 2 & Measuring actual performance. \\
\hline Step 3 & $\begin{array}{l}\text { Comparing actual performance with the specified standards of } \\
\text { performace. }\end{array}$ \\
\hline Step 4 & $\begin{array}{l}\text { Evaluating the result and initiating corrective action if the } \\
\text { standars are not achieved. }\end{array}$ \\
\hline
\end{tabular}

In order that the education quality control activities at the private higher education institutions conducted by Private Higher Education Coordinating Board of Region III Jakarta can run effectively, there are four stages that must be undergone; 1) Setting standards of performance; 2) Measuring the real performance in which the leaders can practically evaluate two things: a) Real output as the result of the behavior of members called the output control; b) Behavior itself, called behavioral control; 3) Comparing the actual performance with the standards; 4) Evaluating the results and performing corrective action if standards are not achieved.

\section{Discussion:-}

There are several things that need to be considered in each stage when Private Higher Education Coordinating Board of Region III Jakarta performs quality control of higher education in the private higher education institutions. They are:

\section{Establishing the Performance Standards:-}

The higher education quality control in the private higher education institutions conducted by Private Higher Education Coordinating Board of Region III Jakarta cannot be separated from various legislation and laws applied. Moreover, Surbakti (2005: 35) asserts that there would be a static legal relation built between the country and its people. It means thatthe regulation of the Private Higher Education Coordinating Board is a unilateral legal act of the government generating rights and obligations for private higher education institutions. Both sides have the same legal status; each party hasrights and obligations. The Private Higher Education Coordinating Board holds the right to demand the private higher education institutions to fulfill its obligations as required in quality control, while the private higher education institutions have rights to be assisted; and the Private Higher Education Coordinating Board provides rules (standards) that must be followed by the private higher education institutions. Rights and obligations of Private Higher Education Coordinating Board and private higher education institutions must be clearly detailed and clearly known by each party and must be determined and stipulated in the regulations.

The establishment of performance standards is a basic function in planning order and management activities, for planning indicates the functions preceding and underlying other management functions. Conceiving this matter whileconducting higher education quality controlin the private higher education institutions, the Private Higher Education Coordinating Boardof Region III has prepared instruments of performance standards-setting by not only including the indicators of efficiency, quality, responsiveness, and innovation, but also other indicators such as quantity, flexibility, and accountability. 


\section{Measuring the Real Performance:-}

With further observation, according to George and Jones (2006: 497), the real performance measurement stagehas two important dimensions: a) Real output as the result of the behavior of members, so-called output control; and b) Behavior itself called behavioral control. In addition, John Miner, in Sudarmanto (2009: 11), mentions that there are four indicators in assessing the performance: a) Quality; including the rates of error, damage, and accuracy; b) Quantity; i.e. the number of tasks generated; c) The use of time in the workplace, i.e. the level of absenteeism, tardiness, effective working time/lost working hours; d) Cooperation with others.

If both views above are integrated, the dimension of output control may include indicators ofresult quality and output quantity while the dimension of behavioral controlmay include the indicators of the use of time in the workplace (level of compliance during working hours, discipline), and cooperation. Related to the output control dimension of the actual performance measurement, it turns out that Private Higher Education Coordinating Board of Region III Jakarta has generated targets exceeding the planned quantity besides meeting the high quality results. Having the relation between behavioral control dimension and the actual performance measurement, Private Higher Education Coordinating Board of Region III Jakarta consistently applies the performance principles based on the organizational values of Private Higher Education Coordinating Board, including: commitment to quality; process and outcome orientation; excellence in service; empathy with customer; reflective in working; open to feedback; integrity as the working coordination; well mannered and providing solutions.

\section{Comparing Actual Performance with the Performance Standards:-}

The next stage that needs to be considered further is to compare the actual performance with the performance standards. To measure this stage, the control indicators of output and employees' behavior of Private Higher Education Coordinating Boardof Region III Jakarta are used. Related to this, Private Higher Education Coordinating Boardof Region III Jakarta constantly evaluates whether the actual performance deviates from the predetermined performance standards and signifies how bigthe deviation occurs. If the performance is higher than expected, the performance standards made by the leaders are set too low and will be raised in the next period in order to provide challenge to the subordinates. How ever, if the performance is too low and the standards are not reached, or if the standard are so high that the employees could not reach it, then the leaders must decide whether they should take corrective action.

Referring to the explanation above, the actual performance of Private Higher Education Coordinating Board of Region III will be compared with the performance standard-setting of the higher education quality in private higher education institutions whchis measured through the indicators of: quality and responsiveness, quality and innovation, as well as efficiency and innovation. The study results indicate that there is an important indicator that needs to be considered in the stage of comparing the actual performance with the performance standards of Private Higher Education Coordinating Boardof Region III Jakarta, namely: staff planning. Riva et al. (2009: 51) state that the purpose of human resource planning is to ensure the availability of labor in the present and in the future, so that every duty can be completed. In this case, the planning staff needed in Private Higher Education Coordinating Board in the implementation of the tasks in the future becomes a priority in order to ensure that the organization activities can be accomplished perfectly. In addition, the employee recruitment can add a limited number of employees so as not to interfere the organization activities in achieving the targets.

\section{Evaluating Results and Corrective Action:-}

Principally, the planning process needs to be evaluated for evaluation is a kind of assessment, and the features of evaluation (Lubis, 1997: 91) are:

a. Addressed to a certain phase in a process after that phase is entirely completed. This is in contrast to the monitoring system aimed at a phase that is still in the implementation process;

b. Corrective to the phase of which has been completed. It means that weaknesses of the system recently used in a completed phase should be found as well as the deviations that have occurred, but more importantly is the finding of causes why the deviations occurred;

c. Prescriptive; something medicating;

d. Addressed to the other organic functions.

In the context of this understanding, evaluation means plans that have been correctly made both in the context of a whole and specifically for a new completed phase; it is examined whether the plan is a supporting factor towards increased efficiency and better growth or whether the plan is a restrictive factor. If the existing plan proved to be a 
supporting factor, then the plan is necessary in order to notify whether the plan cannot be used as a greater motivating factor. However, if the existing plan proved to be a restrictive factor towards the increased efficiency and more rapid growth, certainly the result is that the plan needs to be repaired, examined, or replaced altogether. Obviously, the results of the assessment planning should enable the organization leaders to make new plans that must be well-performed.

Related to that matter, the evaluation and corrective action taken, if standards are not achieved by Private Higher Education Coordinating Boardof Region III Jakarta, is conducted through coordination and communication in regular meetings and of which are not usually held at a certain time. There are a lot of discussions followed up along the progress made by comparing the targets, purposes, or standards of performance that have been previously set. Although the target of higher educationquality controlin the private higher education institutions has been achieved, but there is an important indicator in the stage of evaluating results and corrective action taken if standards are not achieved, which is: indicator of corrective action against the implementing elements. In other words, Private Higher Education Coordinating Boardof Region III Jakarta is improving it quality of duty orthe quantity of employees where as the burden of working unit is faced to the constraint of accuracy and even the constraint of limited time in the completion of its working result.

\section{Conclusion:-}

Quality control of higher education in the private higher education institutions conducted by Private Higher Education Coordinating Boardof Region III Jakarta is effectively conducted through the stages whose concept was developed by George and Jones (2006), including: 1) Establishing theperformance standards;2) Measuring actual performance; 3) Comparing actual performance with the standards; 4) Evaluating the results and applying improvement if standards are not achieved.At the first stage, the measurement of the implementation of performance standards applies indicators of quality, efficiency, responsiveness, and innovation, coupled with the indicators of result quantity, flexibility, and accountability. The second stage is the measurement of the dimensions of output and behavioral control generating the target achievement ofthe higher education quality control at private higher education institutions. At the third phase, it is found that in performing the higher education quality control in the private higher education institutions, Private Higher Education Coordinating Boardof Region III Jakarta pays less attention to the staff planning. At the fourth stage, the output performance target is achieved, although the Private Higher Education Coordinating Boardis still oriented to evaluation and corrective actions against the indicator of the working plan/task elements rather than the indicator of executing elements. This indicates that there is an improvement of the third stage considering that staff planning needs special attention for Private Higher Education Coordinating Board of Region III Jakarta.

\section{References:-}

1. Brantas, 2009, Dasar-Dasar Manajemen, Bandung: Alfabeta.

2. Creswell, John. W, 1994, Research Design Qualitative and Quantitative Approaches, California: Sage Publication.

3. Dessler, Gary, 1986, Manajemen Personalia: Teknik \& Konsep Modern, translated by Agus Dharma, Jakarta: Erlangga.

4. Griffin, Ricky W, 2004, Management, translated by Wisnu Chandra Kristiaji. Jakarta: Erlangga.

5. Gaspersz, Vincent, 2009, Total Quality Management (TQM): Untuk Praktisi Bisnis dan Industri, Jakarta: PT Gramedia Pustaka Utama.

6. Jones, GR and George, JM, 2006, Contemporary Management, New York, USA: McGraw-Hill Companies.

7. Lubis, Ibrahim, 1997, Pengawasan Proyek Pembangunan, Jakarta: Sinar Harapan.

8. Plunkett, WR, \&Attner, RF, 1997. Management: Meeting and Exceeding Customer Expectations, 6th Ed, USA: Prentice Hall, Inc.

9. Puspopranoto, Sawaldjo, 2006, Manajemen Bisnis: Konsep, Teoridan Aplikasi Jakarta: PPM.

10. Robbins, SP \&DeCenzo, DA, 1995, Fundamental of Management: Essensial Concepts and Application, New Jersey, USA: Prentice-Hall International, Inc.

11. Rivai, Veithzal dan Deddy Mulyadi, 2011, Kepemimpinan dan PerilakuOrganisasi, Edisi Ketiga, Jakarta: PT Rajawali Pers.

12. Sudarmanto, 2009, Kinerja dan Pengembangan Kompetensi SDM. Yogyakarta: Pustaka Pelajar.

13. Sallis, Edward, 2010, Total Quality Management in Education, Yogyakarta: IRCiSoD.

14. Surbakti, Ramlan, 2005, Perspektif Baru Mengenai Hubungan Negara Dengan Masyarakat, Jakarta: Journal. 